\title{
Drosscapes or Brownfields? Differing processes to bring redundant industrial land, including military sites, back into productive use
}

\author{
C. M. Clark \\ Fellow, Wessex Institute of Technology, UK
}

\begin{abstract}
'Drosscapes': huge areas of waste and wasted land including ex-military land lie abandoned as a result of the socio- and spatio-economic processes of deindustrialization, post-Fordism and technological innovation. The earlier term 'brownfields' does not have the dynamic implications of the re(land)scaping of 'drosscapes'. The helpfulness of the two definitions towards stimulating reuse of redundant military sites is explored in this paper.

Since 1990 more than 600,000 abandoned and contaminated waste sites, including military sites, have been identified within American cities. It is difficult to quantify brownfields across Europe, where countries have no common legal definition for their redundant industrial land. However, the US can afford to leave a huge proportion of these sites fallow, while European countries, short of land, have a commitment to varying degrees to remediate their brownfields and reuse them, but disposal systems of state land have a major impact on land use outcomes. While free transfer to community interests and tax breaks to facilitate reuse are possible in the US, other countries, such as the UK and Germany, require achievement of the highest price at maximum use value, with consequent effects on new land uses.

These contrasts are a product of geography and history, but the US has exemplar transfer processes and fiscal regimes, particularly for its former military sites, which offer useful lessons to other countries. Best practice occurs in Europe, but the lack of local input, recompense and knowledge transfer mechanisms may mean that there is little potential for the collection and transmission of individual sites' experience into a model national or international process. Experience is drawn from examples on both sides of the Atlantic to demonstrate that the US and Europe have lessons to learn from each other on how to rise to a common challenge: the beneficial reuse of military brownfields. Keywords: drosscape, brownfield, brownfields planning, sustainable development planning.
\end{abstract}




\section{Introduction}

Drosscapes or Brownfields? Processes differ in the US and Europe for bringing redundant industrial land, particularly military sites, back into productive use.

As governments regroup their military operations in response to geopolitical change, new priorities and technological developments, large tracts of defence land in the US and Europe are being abandoned. They are among the more than 600,000 unused and contaminated waste sites identified since 1990 within American cities (EPA [2]). While the Environmental Protection Agency produces detailed statistics for the US, it is difficult to quantify brownfields across Europe, where countries have no common legal definition for their redundant industrial land - or for the military subset within the total. Berger [1] describes these sites as 'Drosscapes': waste and wasted land abandoned as a result of the socio- and spatio-economic processes of deindustrialization, postFordism and technological innovation. His study of unused land in the US includes a number of military brownfields. Brownfields are defined in many different ways; the helpfulness of the two definitions towards stimulating civilian reuse is explored in this paper.

Military secrecy means these enclaves are often unknown to their host communities. When they become available for reuse they present an enormous challenge for sustainable reuse - to design professionals: architects, urban designers, planners and landscape architects - but also to developers, financiers, environmental regulators and local communities, who may be unaware that these sites exist or have any idea about their potential. "As degraded and interstitial entities, drosscapes have few stakeholders, caretakers, guardians or spokespersons. This requires the designer to search for, identify, and educate the stakeholder or group most likely to realize the need for change" [1, p.239].

The US can afford to leave a huge proportion of them fallow, while European countries, short of land, have a commitment to varying degrees to remediate their brownfields and reuse them. This contrast is a product of geography and history, but the US does have exemplar transfer processes, particularly for its former military sites, which offer useful lessons to other countries [3].

\section{How much land?}

As an important consequence of downsizing, the closure of military and naval bases clearly has major economic and land use effects, particularly in areas where there has been an historic concentration of military activity. Defence cuts are often politically and financially driven. Before the first US base closure round, there were approximately 500 domestic military bases. The closure rounds in 1988, 1991, 1993 and 1995 were paralleled by cuts in military personnel. From 1989 to 1997 the US Department of Defense reduced total active duty military strength by $32 \%$, a percentage that was increased to $36 \%$ by 2003 as a result of the 1997 Quadrennial Defense Review [QDR]. These 
represent $21 \%$ of the military installations in the continental US - leaving about 400 active bases. By 1997 the Department of Defense had already reduced its overseas base structure by almost $60 \%$ with operations ceasing at over 960 facilities. By 199927 of these had been redeveloped [1, p. 66]. The US Army in Europe alone closed the equivalent of 12 US major manoeuvre bases, a process that was expected to save the Defense Department more billions of dollars. The process of reduction continues: one 1998 study suggested that 20 to $25 \%$ of the military's infrastructure could be considered surplus. In 2002 Phil Grone, principal assistant deputy undersecretary of defense for installations and the environment, estimated the next round of base closures in 2005 could save \$6 billion a year, even if it cut only $12 \%$ of DoD's military infrastructure. Grone indicated that an analysis to "shed excess capacity" would be completed in 2004, before the Pentagon decided how many bases must be closed in the 2005 BRAC round. In March 2004, the Department of Defense released its justification behind the 2005 base-closure round, citing 24\% excess in military infrastructure. Even taking into account the costs of environmental cleanups, these disposals saved the military about $\$ 16.7$ billion, and they were expected to generate more than $\$ 6$ billion a year in future savings. The website www.globalsecurity.org/ military/facility/brac lists the bases closed in each round. However, these estimates by the General Accounting Office did not include $\$ 3.5$ billion in anticipated environmental costs, or $\$ 1.5$ billion still to be spent to help communities, an important characteristic of the US disposal system. The 2005 Base Realignment and Closure process proposed to close more military installations than the last four rounds combined. The result is that since the early 1990s, three waves of military-base closings have resulted in the sale and conversion of more than a hundred thousand acres of federal land (and thousands of buildings) to private redevelopment (US Department of Defense, cited in Berger [1], p.220). In 2008 the US federal government pledged to purge military bases of 50 million unused square feet in the next five years.

Disposal of defence land in Europe too, has rapidly gathered pace: the Bonn International Centre for Conversion estimate that up to 4,733 hectares - more than 8,000 sites - may have been transferred in the period from 1990 to 2000 . In the UK The National Land Use Database of Previously Developed Land (NLUD PDL) database in existence for the past ten years, aims to "provide a consistent, comprehensive and up to date record of all Previously Developed Land and buildings in England that may be available for development, whether vacant, derelict, or still in productive use", but it does not identify ex-military land within this definition [4]. Another indicator of scale is the money raised from land sales. In 2003/4 the UK's Defence Estates (the Ministry of Defence's property arm) had the country's largest spending power, with a budget of $£ 1.5 \mathrm{bn}$, some of which must be generated by land sales as well as taxes. The effect on local economies of super-power withdrawal - in Asia as well as in Europe - has been considerable. As well as economic impacts in the US, closure of overseas US, as well as Soviet bases, has had enormous consequences for local people and local economies. 


\section{State land disposal processes}

I have described elsewhere the stark contrast between top-down state control and maximisation of financial value in the UK and Germany and the locally controlled and federally funded US system - which includes the possibility of free transfer to meet local social needs [5]. In the US, once the list of recommended closures of military sites by the Base Reuse and Closure Commission (BRAC) is accepted by legislators, the Office of Economic Adjustment (OEA) of the Department of Defence offers help to local communities with reuse planning - well in advance of the exit of military personnel. Community and base work together to determine a reuse plan. The Department of Defense (DoD) Office of Economic Adjustment (OEA) funds are available to local communities to hire planning staff and consultants to prepare the actual planning document, as well as for other types of planning and economic studies. In most cases the community or region forms a base conversion committee to work with OEA throughout the Base Reuse process (BRAC). An agreed plan of recording, decontamination, regeneration of the local economy, new public access to base facilities, ecological and environmental protection follows, controlled and inherited by local interests. The Local Redevelopment Authority (LRA) is recognized by the Secretary of Defense through the OEA to represent the community. A mayor, a city council, an economic development organization, or another strong political leader in the area often initiates the committee. Recommendations of the BRAC Commission accepted by legislators are never overturned [6].

As the plan is formulated, there are several disposal mechanisms for conveyance of DoD sites to new users: Public Benefit Conveyances, Homeless Assistance Conveyances, Negotiated Sale to public bodies for public purposes at fair market value, and Advertised Public sales to the highest bid, but these must be 'approved by the military'. Parts of the site may be sold piecemeal, as long as the land uses conform to the agreed masterplan. According to one participant, the BRAC process is complex and cumbersome and it is evolving, but public benefit remains the determining factor. In contrast, sale of whole sites at once to the highest bidder - in the UK - results in quite different, high financial return land uses, which may bring less benefit to the local community but recompense to the national Treasury [3].

\section{Case study: Brunswick Naval Air Station Maine}

An impressive example of how the BRAC process works in practice are the current plans for redevelopment of Brunswick Naval Air Station in Maine, in a state where jobs are scarce and rising oil prices particularly damaging. The station was developed in the early 1940s in WWII to train British and Canadian pilots because it was too dangerous to train them in Scotland. Before that the land was farms and forest. It was acquired through eminent domain: the acquisition of private property for public purposes - building roads, highways etc. It consists of 3,300 acres of the main base and the 77-acre McKeen Street 
housing and Brunswick Transmitter site, also to be disposed of. Brunswick Naval Air Base was a significant employer: it had $\$ 40 \mathrm{~m}$ a year payroll of 6000 military and naval personnel, plus 5000 associated jobs; a larger workforce than the 3,400 jobs at Bath Ironworks, the only other major employer, which builds ships for the navy. In 2005 Congress voted for the base's closure by September 2011. Its surroundings include commercial activity, colleges and rural lowdensity housing. Sixteen local towns' economy is affected by the closure.

The Reuse Master Plan funded by the OEA and adopted with extensive local input over eighteen months had to balance the local community's needs for economic development, public facilities and amenities and the needs of the homeless. This case deviated from the BRAC model of a town actually running the planning process: a separate entity was set up instead with a focus on regional identity - a development authority appointed from local interests by the state governor to run the planning process. This began with a detailed facility survey. Very early consultation sessions were held with the community to identify their hopes and fears, and bus tours of the base took place once a week all summer. Many people had never been on the base before, or only a long time ago. Consultation of different segments of the community included military and civilian workers on the base, high school students and the public at large. 1800 people responded - via an interactive website. Comments, questions and information were posted on it, and responses sought from community leaders, general citizens, businesses, and environmentalists. Workshops produced design guidelines showing how the site will look and feel. The area suffers from the lack of affordable housing, and appropriate uses included an industrial/ business park and educational uses. Topical issues seminars were held on housing, transportation - traffic impacts, transit opportunities and pedestrian systems and environmental issues - clean up and disposition strategies. As other countries have found, record-keeping on contaminating materials was previously much less stringent than it is now, which sometimes means unwelcome discoveries are made during the survey process. Ecological concerns are important: there are Acquifer Protection Zones and special ecosystems in areas inaccessible by vehicle. New utility systems would be required for new uses.

Not knowing that the base was going to close, the Navy had spent $\$ 160 \mathrm{~m}$ in the last six years on two runways - a significant investment. Four conceptual plans were produced - with and without aviation. The economic and operational feasibility of a civil airport was investigated, and the public preference was for aviation uses - which would hopefully provide continuity of aerospace employment. Further development of composites for boatbuilding, aircraft and energy applications, research and development and electricity generation - an urgent priority for Maine - with homes heated by solar, thermal, hydrogen, wind, tide, could all take place on the site. The intention is to develop an economic engine for the larger Brunswick region, as well as active and passive recreation, wildlife habitat but not new housing. British multi-national Balfour Beatty owned the navy housing, once rented to the navy, but the land underneath was subject to the masterplan, and there was no real housing market once the navy leaves. The effects of the proposed new uses on wages, income tax and 
commercial and property taxes were considered. A display of static aircraft would require state funding from Maine's capital Augusta to develop and establish a naval air museum. South Maine Junior College bought 35 acres of the airbase to put into their campus - between Bath and Brunswick and Cook's Corner. A Homeless Trust Fund was to be capitalised by future base property sales/transfers or property exactions.

The Plan aims to promote a strong sense of place, and is based on smart growth principles. Members of the regional consortium working on base closures travelled to other bases such as Plattsburg Airforce Base, Pease Air Base and Fort Devens Massachusetts, but each base and community is dramatically different. The departure of thousands of military and families for Jacksonville Florida and of the civilians offered federal jobs elsewhere will have a dramatic effect on many local businesses supplying the base. But there is no federal money for infrastructure - the development authority has to raise the money. According to Steve Levesque, the planner who is director of the process, individual states are going to have to step up their assistance to fund reuse of military bases. As he says - and it's true the world over - the armed services are not interested in the public interest - but in fighting wars. The fabric of the community has been closely entwined with the military. They have been in Brunswick for 50 to 60 years, and brought worldwide perspectives to a small community. Thousands of local people thronged the base for the last air show in September 2008. One in four residents has military ties; a completely new identity will have to be forged [7].

\section{Abolition of the UK Crown Exemption and its implications for defence disposals: case study of the Royal Naval Hospital Haslar, Portsmouth Harbour, UK}

An important change to the UK system was the abolition of the Crown Exemption from civil law, including planning, in 2006, although it still remains operational in Norway. Case studies around Portsmouth Harbour illustrate the profound effect of this change. In November 2008 the British Ministry of Defence (MOD) funded a three-day workshop of local and professional interests to come up with a master plan for Haslar Hospital Gosport, one of their most important and complex historic properties. Significantly, the stimulus to greater consultation was the changing status of defence lands - the loss of the Crown Exemption. MOD Defence Estates now have to engage in statutory planning whereas before abolition, they would bring forward substantial proposals already agreed with developers - as they did at Gunwharf and the Royal Clarence Victualling Yard nearby - and merely ask for responses. This is not the first time that the Ministry of Defence has used this particular planning tool, but they have not done so for a historic site before. They have carried out major consultations in the urban extension of Aldershot and Catterick, and at RAF Cosford (internal to the MOD's competing operational uses). The gain to the MOD is establishing a site's value, and, of course, smoothing its future course through the planning system, as well as, hopefully, incorporating local people's knowledge and 
expertise into the plan. As the Defence Estates officers who commissioned the process said, this method goes further than the usual consultation, for example in the range of external stakeholders.

The Haslar workshop was run by the Prince's Regeneration Trust, using the Enquiry by Design process. The Trust is a charity to preserve buildings, monuments, structures or sites of particular beauty or historical and architectural interest and to promote urban or rural regeneration in areas of social and economic deprivation. The Enquiry by Design process is a planning tool trademarked by the related Prince's Foundation for the Built Environment, an educational charity working to improve the quality of people's lives by teaching and practising traditional and ecological ways of planning, designing and building. The process involves stakeholders and the local community working together to shape a place, testing every issue by drawing it. This process differs fundamentally from the conventional planning process in that data is built up on a plan-based system, a crucial element in achieving sustainable communities. It aims to deliver masterplans that are based on enduring design principles and to develop the place-making skills of the participants.

The workshop was focussed on the reuse of the many historic buildings within the hospital, many of them listed. Potential areas for new buildings were to be identified, the importance of features of the Registered Historic Landscape considered, types of uses identified, provision made for vehicular and pedestrian access in and around the local area - all drawing on the experience and local knowledge of the key stakeholders. Participants formed five specialised groups which developed final drawings of overall strategies for movement and connectivity, land use, heights and massing, landscape and ecology, heritage plan, phasing and mix and commercial viability. The challenge at Haslar is the maximum historic fabric, and its isolation - because in the eighteenth century military hospitals were built away from the town. The aim is to reintegrate the site with the rest of Gosport. It would be vulnerable if left empty. Defence Estates do not want to spend three or four years deciding its future, but to identify beneficial uses more quickly. No single entity is likely to buy the whole site, but they expect a consortium or a trust like Greenwich to take on the site [8].

\section{Contamination and its mitigation or removal - who pays?}

In the UK a national agency, English Partnerships, sometimes takes on military sites, but is not as generously financed as the US Superfund, which is directed at the National Priorities List - created by the federal government to reclaim and redevelop contaminated waste landscapes whose problems are beyond local capacity to solve. In 2006 there were nearly 1,300 sites awaiting Superfund cleanup and reclamation. According to Berger [1, pp. 67-68], Denver Colorado and the communities along the Rocky Mountain Front Range exemplify the new confluence of ecological attitudes and practices concerning contaminated land uses, but achievement of acceptable levels of cleanup is far from easy. Sites along the Front Range urbanized area totalling about 53,000 acres are in the 
process of being converted from toxic land into redevelopable areas. The cleanup cost alone is estimated to be no less than $\$ 11$ billion. The 27-acre Rocky Mount Arsenal was one of the largest urban toxic-land reclamation projects in America. A former chemical weapons, nerve gas and pesticide manufacturing site, it was designated as a federal refuge in 1992. The Rocky Flats nuclear-trigger manufacturing plant, until 1989 operated by the US Department of Energy, is also being converted into a national Wildlife Refuge managed by the US Fish and Wildlife Service. After a raid by the FBI and the EPS, operations at Rocky Flats were shut down in 1989 in response to alleged violations of environmental statutes. At one time Rocky Flats stored more than fourteen tons of plutonium. Building 771 was called "the most dangerous building in America". Groundwater beneath the site, on site ponds and lakes and reservoirs off-site were found to contain plutonium contamination. More than two million people in the eight-county Denver metropolitan area live within ten miles of Rocky Flats, and the closest house is within two miles. Currently the site is surrounded by open space, but urban growth pressures are pushing residential and commercial development closer to the facility. Hiking and biking trails, nature-viewing areas, wetland and prairie habitat protection, a visitor centre and active community education are planned, but traces of plutonium, americium and uranium were found in some mule deer in the buffer zone around the weapons production area [1, pp. 67-69].

In contrast, perhaps with less serious contamination and a more central location, the former El Toro Marine Corps Air Station in Irvine California in America's hottest real-estate market was sold at auction for a record $\$ 650$ million for 3,400 new homes. Other federal or state facilities are sometimes the successor owners. Papago Military Reservation Phoenix/Scottsdale Arizona contains a military museum and a facility used by the Arizona National Guard [1, p. 226].

\section{Brownfields and drosscapes - definitions}

In 2003, Oliver et al. [9] reported on an 'international momentum... towards a definition of brownfields that is equivalent to land affected or potentially affected by contamination...' as the term is almost exclusively understood in the US. CABERNET, however, defines brownfields as 'sites that have been affected by the former uses of the site and surrounding land; are derelict and underused; may have real or perceived contamination problems; are mainly in developed urban areas; and require intervention to bring them back to beneficial use' (based on the original CLARINET2 definition). This definition is closer to the common usage in the UK of the term brownfield to denote previously developed land (PDL) [9].

In contrast to this static description for such sites, dross is understood as a natural component of every dynamically evolving city. As such it is an indicator of healthy urban growth. "The term drosscape implies that dross, or waste, is scaped, or resurfaced, and reprogrammed by human intentions...Drosscaping as a verb is the placement upon the landscape of new social programs that 
transform waste (real or perceived) into more productive urbanized landscapes" [1, p. 237]. Drosscapes "require the designer to shift from tacit and explicit knowledge (designer as sole expert and authority) to complex interactive and responsive processing (designer as collaborator and negotiator)...In many cases a client may well not even exist but will need to be searched out and custom-fit in order to match the designer's research discoveries. In this way the designer is the consummate spokesperson for the productive integration of waste landscape in the urban world" (Berger [1 pp. 3-4]). This manifesto for the design professions is backed up in the US by the Superfund, and as far as military sites are concerned, by the BRAC process, which puts the local community in the driving seat. One outcome of the drive to intensify density in urban areas in order to make them more sustainable might be to limit urban sprawl.

In Europe with a more confined land area and many different cultures and political systems this more dynamic term is useful, implying a positive and active search to bring these problem sites, both civilian and military, back into sustainable new life. Rachel Woodward [10] made a plea for statistical clarity on how much and where UK military sites are. At least the abolition of the Crown Exemption now subjects them to civil planning processes, but there is no equivalent of the DoD Office of Economic Adjustment to help local communities find sustainable new uses for them in the remit of the Ministry of Defence property agency, Defence Estates, whose task is to raise money via sales of redundant sites for the central Treasury.

\section{Federal grants and fiscal creativity}

In addition, the US has examples of fiscal creativity that galvanise even the most difficult sites. As already mentioned since the 1990s US brownfields have received increasing attention from the federal government. From 2003 to 2005 more than \$225 million in federal grants were given to states to promote the redevelopment of contaminated land. Most were former urban industrial production sites. "Today developers seek out contaminated sites instead of clean ones" (Berger [1, p. 70]) because they can generate a higher rate of return from contaminated properties than from uncontaminated ones. New federal subsidies make this possible. Tax increment financing allows for the taxes assessed on property value to be used for redevelopment activities such as infrastructure improvements [11].

Another model is the industrial development corporation. The Philadelphia Industrial Development Corporation (PIDC), a private, not-for-profit body, was created in 1958 by The Greater Philadelphia Chamber of Commerce and the Commerce Department of the City to promote economic development and job creation throughout the City. The Navy Yard is among the most architecturally significant US naval bases and its long-term conversion to civilian uses using tax concessions is also an impressive exemplar. From 1874 the Navy had constructed a miniature city on a marshy spit of Delaware waterfront, continuing the street grid in the Center City District (CCD), located 3.5 miles to the north on Broad Street. At the peak of World War II the yard employed 60,000 people 
working in almost 300 buildings. By 2000, when the Navy handed the base over to the city's Industrial Development Corporation, most of the yard had long been abandoned. The 132-year-old base has tree-lined, traffic-free streets of Georgianrevival officers' mansions giving way to redbrick industrial workshops, where for decades muscled workers bent and riveted steel into battleships.

After it closed in the late 1990s, Robert A M Stern Architects was hired by the city development company to produce a master plan and marketing concept for the yard's historic industrial core and the surrounding 1,200 acres of undeveloped land. "The gauzy watercolor renderings from the 2004 plan offer a bird's-eye view of an orderly suburban office park, some vaguely Soviet housing blocks, and a variation on Baltimore's Inner Harbor. It took years for the city to wrap its mind around the huge site, which is almost as big as Philadelphia's downtown" (www.navyyard.org/MainMenu.html). The Stern master plan, produced jointly with developer Liberty Property Trust, offered a basic framework, turning the main section of the yard into an office and industrial park in order to retain businesses that might otherwise be tempted by inexpensive low-rise suburban spaces with wide-open parking lots. The shipyard, with good highway access, was rechristened the Philadelphia Naval Business Center. Most of the existing buildings within The Navy Yard Historic Core ranging in size from 3,000 to 900,000 square feet, were within the tax-free Keystone Opportunity Improvement Zone (KOIZ) where no city and state business taxes are payable by qualifying companies until 2018. Rehabilitation of historic buildings using tax credits has been recognised by several preservation awards; and Philadelphia's trendiest Urban Outfitters (UO) relocated its headquarters from the city centre to a large workshop in the navy yard (www.navyyard.org/MainMenu.html).

The most extreme fiscal tool - reducing the value of a military site to zero was used for Governor's Island off the tip of Manhattan in New York. The Island's strategic location lead to its use as a military facility by British and American forces for over 200 years. Following the British evacuation of New York in 1776, the Americans fortified the Island in fear of further advances by the British navy. After the Revolution the Island reverted back to New York State. In 1794, as part of the country's coastal defences, construction began on Fort Jay. In 1800, New York transferred the Island to the US government for military purposes. Between 1806 and 1809, the Army reconstructed Fort Jay and built Castle Williams on a rocky outcropping facing the Harbour. During the War of 1812 artillery and infantry troops were concentrated on Governors Island. During the American Civil War, it was used for recruitment and as a prison for captured Confederate soldiers. Throughout World Wars I and II, the Island served as an important supply base for Army ground and air forces until the 1960s. Liggett Hall, a large structure designed by McKim, Mead \& White, was built and became the first Army structure to house all of the facilities for an entire regiment. As the result of the consolidation of U.S. Military forces in 1966, the Island was transferred to the Coast Guard: it became their largest installation, serving both as a self-contained residential community of 3,500, and as a base of operations for the Atlantic Area Command and Maintenance and 
Logistics Command as well as the Captain of the Port of New York. Governors Island has been the site for a number of historic events. In 1988, President Reagan hosted a U.S.-U.S.S.R. summit with Mikhail Gorbachev on Governors Island, and in 1993 the U.N. sponsored talks on the Island to help restore democratic rule in Haiti.

In 1995, the Coast Guard closed its facilities. In the face of a potential value of trillions of dollars, in January 2001 President Clinton designated 22 acres, including the two great forts, as the Governors Island National Monument, and on April 1, 2002, President George W. Bush, Governor Pataki, and Mayor Bloomberg announced that the US of America would sell Governors Island to the people of New York for a nominal cost; it would be used for public benefit. At the time of the transfer, deed restrictions were created that prohibit permanent housing and casinos on the Island - the high value land uses first suggested. The Island was transferred to the people of New York on January 31, 2003, through the Governors Island Preservation and Education Corporation. A design competition was held to clear all post 1960s development and create a new public park for the people of New York via the dedicated ferry. The Island is now thronged with cyclists, artists, schoolchildren and visitors' tours to its historic sites, excellently interpreted by the National Parks Service (www.govisland.com)

\section{Conclusion: sharing experience across national frontiers}

Getting together to share responses to this worldwide challenge across many different cultures and political systems happens only intermittently. In the 1970s the British Urban Regeneration Association held a conference in Bremen to explore experience of the transition from military to civilian uses. Rochefort in southwest France was the location for seminar focusing on historic dockyards in Europe in September 2007. In April 2008 government representatives and volunteers responsible for historic dockyards and ship preservation in Nordic countries, Kronstadt near St. Petersburg, Portsmouth UK and Rochefort were convened by the Governing Body of Suomenlinna in Helsinki Finland for a Round Table to discuss management of these specialised historic defence sites and to share experience of running them. There is clearly scope for more such events.

What might be useful would be an international version of the US Association of Defense Communities (ADC), which has 1,200 members nationwide. It is the voice for communities and states with a significant military presence, uniting the diverse interests of communities, state governments, the private sector and the military on issues of base closure and realignment, community military partnerships, defence real estate, mission growth, mission sustainment, military privatization, and base redevelopment. It has monthly meetings via conference call and biennial big meetings. It is financed through membership, which pays for the hire of staff based in Washington DC to lobby government (www.defensecommunities.org). 
The disposal of historic defence land is a complex planning challenge, qualitatively different from ordinary changes of use because of the unusually wide range of interested stakeholders and their expectations. The qualitative dimension of these special cases of redevelopment is often excluded from consideration. The question of whether the public interest exists in these disposals, and if so where it could be located remains open. The power context inside which the interested parties interact over their future needs analysis in order to understand how and why the disposal and transition process takes place as it does, and how it could be modified so that a fuller range of inputs could be taken into account, affecting the quality of the outcomes.

\section{References}

[1] Berger A Drosscape Wasting Land in Urban America Harvard Design School Princeton Architectural Press New York 2006

[2] Environmental Protection Agency 2003 “476.7 Million in Brownfield Grants Announced" May 102005 and "EPA Announces \$73.1 Million in National Brownfields Grants in 37 States and seven Tribal Communities" June 202003 US EPA official website http://epa.gov/brownfields/ archive/pilot_arch.htm (accessed May 21 2005)

[3] Clark C "White holes: Decision-making in disposal of Ministry of Defence Heritage sties" PhD thesis University of Portsmouth 2002

[4] NLUD Partnership - English Partnerships and CLG News release 24/09/2008 'Major data study holds key to unlocking brownfield sites'

[5] Clark C 'Do naval and civilian waterfront renewals have lessons to teach each other?' Brownfield Sites II Assessment, Rehabilitation and Development eds. A Donati, C. Rossi CA Brebbia Wessex Institute of Technology Press pp. 171-179 1SBN I-85312-719-1; Clark C Defence heritage moves onto civilian futures Brownfields 2006 19-21 July Tallinn, Estonia 2006

[6] Koenig SB Reporter Brunswick Times Record Interview with Celia Clark 4 September 2008

[7] Levesque S Mid Coast Regional Development Agency stevel@mrra.us, Interview with Celia Clark 5 September 2008

[8] Clark C 'Royal Hospital Haslar: Enquiry by Design Workshop November 3-5 2008' Dockyards The Naval Dockyards Society December 2008 Volume 13 Issue 2 www.navaldockyards.moonfruit.com

[9] Lee Oliver, Uwe Ferber, Detlef Grimski, Kate Millar, Paul Nathanail The Scale and Nature of European Brownfields 2003

[10] Woodward R Military Geographies, Blackwell Publishing Ltd, 2004

[11] Hortense L "Squeezing Green out of Brownfield Development" National Real Estate Investor June 12003 quoted in Berger op cit p70). 